\title{
Newcomer knowledge, attitudes, and beliefs about human papillomavirus (HPV) vaccination
}

Lindsay A. Wilson ${ }^{1}$, Amanda M. L. Quan ${ }^{1}$, A. Brianne Bota ${ }^{1}$, Salima S. Mithani ${ }^{1}$, Michelle Paradis ${ }^{1}$, Cindy Jardine ${ }^{2}$, Charles Hui ${ }^{3}$, Kevin Pottie ${ }^{4}$, Natasha Crowcroft ${ }^{5}$ and Kumanan Wilson ${ }^{1,6^{*}}$ (i)

\begin{abstract}
Background: Human Papillomavirus (HPV) is the most common sexually transmitted infection in Canada and around the world. Vaccination is an effective prevention strategy, but uptake is low, especially among newcomers to Canada. We sought to understand newcomers' knowledge, attitudes, and beliefs (KAB) on HPV and HPV vaccination and their role in HPV vaccine acceptance.

Methods: Newcomers were defined as individuals born outside Canada, (i.e., individuals born in a different country, the majority of whom are immigrants or refugees, but also includes students and undocumented migrants). Eligible participants were newcomers, aged 16 or older and who could read or write in English, French or Arabic. Surveys were administered in two community health centres in Ottawa, Canada that primarily engage with newcomer populations. Follow-up interviews were conducted either at the community health centre or over the phone, depending on participants' preferences.

Results: Fifty participants completed the survey, the majority of whom were women (74\%) and spoke Arabic as their first language (54\%). Seven participants completed supplemental interviews to complement their survey responses. The majority (70\%) of participants had not previously heard of HPV. Less than half (46\%) knew that the vaccine is effective in preventing certain types of cancer; nearly $40 \%$ incorrectly believed the vaccine could cure HPV. Qualitative interviews supported the survey findings.

Conclusions: Despite a lack of HPV knowledge due to cultural and language barriers, there is still a strong desire among newcomers to receive the vaccine, especially when accompanied by a physician recommendation. Cultural and languageappropriate resources are needed to help newcomers make informed vaccination decisions and promote HPV vaccine uptake.
\end{abstract}

Keywords: Human papillomavirus (HPV), Vaccine, Newcomers, Barriers to care, Canada

\footnotetext{
*Correspondence: kwilson@ohri.ca

${ }^{1}$ Clinical Epidemiology Program, Ottawa Hospital Research Institute,

Administrative Services Building, Box 684, 1053 Carling Avenue, Ottawa, ON K1Y 4E9, Canada

${ }^{6}$ Department of Medicine, University of Ottawa, 451 Smyth Rd, Ottawa, ON K1H 8M5, Canada

Full list of author information is available at the end of the article
}

(c) The Author(s). 2021 Open Access This article is licensed under a Creative Commons Attribution 4.0 International License, which permits use, sharing, adaptation, distribution and reproduction in any medium or format, as long as you give appropriate credit to the original author(s) and the source, provide a link to the Creative Commons licence, and indicate if changes were made. The images or other third party material in this article are included in the article's Creative Commons licence, unless indicated otherwise in a credit line to the material. If material is not included in the article's Creative Commons licence and your intended use is not permitted by statutory regulation or exceeds the permitted use, you will need to obtain permission directly from the copyright holder. To view a copy of this licence, visit http://creativecommons.org/licenses/by/4.0/ The Creative Commons Public Domain Dedication waiver (http://creativecommons.org/publicdomain/zero/1.0/) applies to the data made available in this article, unless otherwise stated in a credit line to the data. 


\section{Background}

Human Papillomavirus (HPV) is the most common sexually transmitted infection in Canada and around the world [1]. It is estimated that $75 \%$ of sexually active Canadians will have at least one HPV infection in their lifetime [2]. HPV infection is the cause of nearly all cervical cancers [1] and can also result in numerous other genital and oropharyngeal cancers [3]. Vaccination has proven to be an effective primary prevention strategy to protect against HPV infection and HPV-associated precancerous lesions [4-6].

Publicly-funded, predominantly school-based HPV vaccination programs were introduced in Canada in 2006, and all provinces and territories now offer publicly-funded HPV vaccination for both boys and girls [7]. Despite the effectiveness and widespread availability of the HPV vaccine, HPV vaccination uptake is estimated to be only $56 \%$ in Canada, well below the goal of $>80 \%$ coverage [8]. Low uptake was also observed in a systematic review evaluating vaccine uptake by parents for their children across 15 countries with HPV vaccination programs, including Canada and the US. Gender was found to be a factor in determining uptake, with vaccination among girls occurring twice as often as among boys [8-10].

A systematic review evaluating $\mathrm{HPV}$ vaccine uptake in Canada also found vaccination rates to be higher in females (57\%) compared to males (47\%) and higher in participants 18 years of age or younger (67\%) [8]. Vaccine cost was found to be a significant barrier to vaccine uptake in Canada, where HPV vaccination costs are only covered for school-aged children $(<26$ years of age for most private insurance plans). Specifically, uptake was less than $14 \%$ when participants were required to pay out of pocket [11]. However, healthcare provider recommendation appears to play an important role in encouraging parents to accept the vaccine for their children $[9,10]$.

One group for whom it is difficult to ascertain HPV vaccination uptake information is newcomers to Canada. More than 200,000 newcomers arrive in Canada each year [12]. These numbers primarily comprise immigrants- individuals choosing to settle in a country other than the one in which they were born - and refugees but also include students and undocumented migrants. Newcomers may not be comfortable answering questions about their vaccination history due to language barriers or cultural norms about discussing sexual health [14]. Immigrants and refugee populations in Canada have been found to have lower screening rates for cervical cancer and higher rates of HPV infection, putting them at increased risk of morbidity and mortality from HPV infection and associated cancers [15-17].

The objective of this study was to better understand the knowledge, attitudes and beliefs (KAB) of newcomers surrounding HPV and the HPV vaccine. The study was guided by the following research questions:

1. What knowledge do newcomers possess regarding HPV and the HPV vaccine?

2. What beliefs and values do newcomers possess regarding HPV and the HPV vaccine?

3. What barriers do newcomers face when accessing $\mathrm{HPV}$ vaccination?

\section{Methods}

\section{Study setting}

This study was conducted in Ottawa, Canada, where immigrants and refugees make up over $20 \%$ of the population [12]. Ottawa-Gatineau has the fifth highest number of foreign-born people in Canada [13]. Among recent immigrants, the most-commonly spoken language is Arabic and the greatest proportion of people originate from Asia (44\%) and Africa (24\%) [13]. The HPV vaccine is offered in publicly-funded, school-based vaccination programs to all students in Ontario when they are in Grade 7 (age 11-12). This study and all study materials were approved by the Ottawa Health Science Network Research Ethics Board (OHSN-REB \#20170913-01H). All participants provided informed written consent prior to participating in any study-related activities. Participants' names and contact information were stored separately from their responses in order to ensure confidentiality.

\section{Participant recruitment}

Eligible participants were:

- Young Adults: Between the ages of 16 and 27 (the upper age limit for which many insurance plans will cover HPV vaccination in Ontario), any gender, did not have children, and were either newcomers or the children of newcomers.

- Caregiver: Over the age of 18, any gender, born outside of Canada, and had one or more children under the age of 18 .

Participants were recruited from two local community health centres (CHCs) in Ottawa that offer a variety of primary healthcare services to patients, including vaccination, and have considerable contact with Ottawa's newcomer population. Identifying appropriate participants was facilitated by gatekeepers at each of the clinics. Those deemed eligible to participate by gatekeepers were introduced to the research staff who provided further details on the study and obtained informed written consent. 


\section{Survey instrument}

The survey was developed in-house based on findings from our previously published systematic review of barriers to vaccination among newcomers [14]. The survey had not been previously validated but was reviewed and revised in collaboration with staff from the $\mathrm{CHCs}$ used as recruitment sites and with the healthcare providers. The caregiver and young adult survey contained questions on demographics, immigration status, knowledge of HPV and HPV vaccine, and vaccine acceptance. There were a total of 14 questions with multiple prompts.

\section{Data collection}

Surveys were conducted between May and July 2018. All participants who had previously heard of HPV and the HPV vaccine were asked to complete 11 additional questions to evaluate their level of HPV knowledge. Participants were also asked questions about vaccine acceptance. The survey was available in English, French, and Arabic. Participants 18 years of age and older who had children of any age were offered the "caregiver" version of the survey. Participants between the ages of 1627 years who did not have children received a "young adult" version of the survey containing a restricted set of questions without references to decision-making for one's children. All surveys were conducted in-person and returned to the research staff on the same day they were completed. The survey was stopped when a maximum of 50 participants were reached.

Semi-structured interviews were held with seven participants out of the fifty who completed the survey and who consented to being re-contacted for the purposes of the study. These interviews took place between June and August 2018, and were administered in English, French, or Arabic by research staff trained in qualitative research. An interpreter was provided to translate between English and Arabic. Interviews were conducted either inperson or over the phone, according to the participant's preference. All interviews were audio-recorded, transcribed verbatim and analysed for emergent themes using a thematic analysis approach [18]. Interviews lasted an average of $25 \mathrm{~min}$, with a range of 15 to 50 min. The interviewees were asked questions about their knowledge, uptake and beliefs around HPV and HPV vaccination (Supplemental Table 1).

\section{Data analysis}

Survey data were analyzed using STATA 15.1 and was summarized using descriptive statistics. Chi-square tests were used to identify differences in HPV and HPV vaccine awareness and willingness to vaccinate across age groups, gender and level of education. Age was categorized into three distinct strata: $16-27,28-44$, and $\geq 45$. Level of education was categorized into three distinct strata: completed high school or less, incomplete college or university and completed college or university. Statistical significance was set at $p \leq 0.05$ [17-20] (18)(18)(18). A thematic analysis approach [18] was used to qualitatively analyze the survey open responses and interviews.

\section{Results \\ Participant characteristics}

Surveys were offered to those deemed to fit the eligibility criteria by the $\mathrm{CHC}$ clinicians. All potential participants deemed eligible by the clinician agreed to participate in the survey $(n=50)$. Participant characteristics are summarized in Table 1. Twenty-seven participants (54\%) chose to complete the survey in Arabic, 11 in English (22\%) and 12 in French (24\%).

Participants from 18 different countries responded. The majority of participants were originally from the Middle East and North Africa $(n=29,58 \%)$ region. Thirty-eight $(76 \%)$ of the participants were female and $24 \%$ were male. Islam and Christianity were the two religions with which participants most commonly identified (60 and 34\%, respectively). Nine (18\%) of the participants completed the young adult survey, whereas the remaining 41 (82\%) respondents completed the caregiver survey. The average age of the young adult group was $22.4 \pm 3.7$ years (range 17-27 years) and the caregiver group was $32.0 \pm 10.1$ (range: $21-57$ ) years. The caregivers had between 1 and 11 children (mean $3.5 \pm 2.1$ ) ranging in age from 0 to 31 years. The majority of the caregiver population were married $(n=34,68 \%)$. $48 \%$ $(n=20)$ of the caregivers had completed some form of postsecondary education.

Seven ( 5 females, 2 male) of the caregiver participants agreed to be contacted for follow-up and completed the interviews. Four of the seven interviewees were from Africa and all interviews were conducted in English or French. Individuals who participated in interviews had between 1 and 11 children. Four emergent themes were identified from the interviews and illustrative quotes are summarized in Table 2.

\section{HPV knowledge}

The caregiver and young adult responses to HPV and HPV vaccine knowledge and beliefs are summarized in Table 3 . The majority $(n=35,70 \%)$ of survey respondents had not previously heard of HPV; 3 young adults and 13 caregivers had heard of HPV and 2 preferred not to say. No significant associations were identified between age group $\left(X^{2}(4, N=50)=1.2845, p=0.536\right)$ or gender $\left(X^{2}(2, N=50)=0228, p=0.637\right)$ and awareness of HPV or age group $\left(X^{2}(4, N=50)=0.5109, p=0.775\right)$ or gender $\left(\left(X^{2}(2, N=50)=0.082, p=0.928\right)\right.$ and awareness of HPV vaccine. Level of education was associated with awareness of $\operatorname{HPV}\left(X^{2}(2, N=41)=6.8742 p=0.032\right)$ or 
Table 1 Descriptive characteristics of 50 newcomer survey respondents in Ottawa, Canada

\begin{tabular}{|c|c|c|}
\hline Characteristic & $\begin{array}{l}\text { Respondents } \\
(N=50)\end{array}$ & $\%$ \\
\hline \multicolumn{3}{|l|}{ Survey Language } \\
\hline English & 11 & 22.0 \\
\hline French & 12 & 24.0 \\
\hline Arabic & 27 & 54.0 \\
\hline \multicolumn{3}{|l|}{ Gender } \\
\hline Female & 38 & 76.0 \\
\hline Male & 12 & 24.0 \\
\hline \multicolumn{3}{|l|}{ Age } \\
\hline $16-27^{\mathrm{a}}$ & 13 & 26.0 \\
\hline $28-44$ & 19 & 38.0 \\
\hline $45+$ & 15 & 30.0 \\
\hline Prefer not to say & 3 & 6.0 \\
\hline \multicolumn{3}{|l|}{ Religion } \\
\hline Christian & 17 & 34.0 \\
\hline Muslim & 30 & 60.0 \\
\hline Agnostic & 1 & 2.0 \\
\hline None & 2 & 4.0 \\
\hline \multicolumn{3}{|l|}{ Immigrant Status } \\
\hline Immigrant & 20 & 40.0 \\
\hline Refugee & 19 & 38.0 \\
\hline Other & 9 & 18.0 \\
\hline Prefer not to say & 2 & 4.0 \\
\hline \multicolumn{3}{|l|}{ Marital Status $(n=41)^{b}$} \\
\hline Single & 3 & 6.0 \\
\hline Married & 34 & 68.0 \\
\hline Widowed & 3 & 6.0 \\
\hline Prefer not to say & 2 & 4.0 \\
\hline \multicolumn{3}{|l|}{ Number of children $(n=41)$} \\
\hline 1 & 4 & 9.8 \\
\hline 2 & 12 & 29.3 \\
\hline 3 & 11 & 26.8 \\
\hline 4 & 5 & 12.2 \\
\hline $5+$ & 9 & 22.0 \\
\hline \multicolumn{3}{|l|}{ Region of Origin } \\
\hline Sub-Saharan Africa & 18 & 36.0 \\
\hline Middle East and North Africa & 29 & 58.0 \\
\hline Other & 3 & 6.0 \\
\hline
\end{tabular}

${ }^{a}$ Nine of the participants in the 16-27 category completed the young adult variation of the survey, while the others had children and thus completed the adult version

${ }^{b}$ Sample size reflects number of participants who completed the Caregiver version of the survey; Young Adults were not asked for their marital status
Table 2 Quotations illustrating emergent study themes from interviews with seven newcomers to Ottawa, Canada

Theme

\section{Lack of HPV Knowledge}

Low Knowledge

Interviewer: Have you heard of HPV before? If yes, what do you know about it?"Nothing" (Participant \#3)

"I think - where I come from, it's not - we're not - most people are not knowledgeable about it because I think it's treated with - it's not treated with as much attention as it should be given." (Participant \#1)

"no, had never heard of it" - (Transcript 5)

\section{Misconceptions about HPV and the HPV vaccine}

"...they go to [the] swimming pool for example, they don't have boyfriends or girlfriends, but because they go to public places, I'm concerned about that [HPV]... maybe with the public toilets they use. I want to make sure they're protected. Public toilets, I'm very concerned about that." (Participant \#6)

\section{Willingness to accept vaccination}

Interviewer: "Do you believe that you would have your children vaccinated against HPV?

"And my kids also, I would love them to get it when they get to the age. Yeah because you don't play with your health, yeah. Health is wealth like they say." (Participant \#1)

"They are very important [vaccines]. As, there is something said at home, I do not know if here we say it, it is better to prevent than cure. We warn like that." (Participant \#4)

\section{Access to vaccination}

\section{Cost}

"They should cover it, that's very sad. Most people those ages [i.e., young adults no longer covered by the school-based programs], they don't have a permanent job, they're working here and there, they can't afford that, it's very hard for them. They should make it easier for them to protect themselves and then they won't have to pay for them to be treated and treated for cancer." (Participant \#6)

"Where I've come from, most vaccines are free [...] The government paid for them to pay for the - for the health workers at those administration boards, the recipients get it for free." (Participant \#2)

\section{Lack of time and healthcare provider recommendation}

Interviewer: "Did your doctor recommend the HPV vaccine for you (or your kids)"?

"It's very hard because when you go to the doctor, you have to limit your reason for going, you wait a lot of time and you have to have just one reason to be there, and it's all a rush. There's no time to mention that [HPV]." (Participant \#6)

\section{Cultural norms}

"I believe this is a bit difficult to speak about .... Africans don't talk a lot about sex with their children. If it's with girls, no it is difficult, with boys I can see us talking a little bit, but not in depth. With girls it is very difficult." (Participant \#7)

Interviewer: "So, do you think you would leave the choice to be vaccinated or not get vaccinated up to your daughter"? Participant \#4: "Yes".

HPV vaccine $\left(X^{2}(2, N=41)=5.8011,=0.055\right)$. When asked whether they had heard of the HPV vaccine one participant responded, "I think - where I come from, most people are not knowledgeable about it because I think it's treated with - it's not treated with as much attention as it should be given." 
Table 3 Knowledge and Beliefs around HPV and HPV vaccine

\begin{tabular}{|c|c|c|c|}
\hline & $\begin{array}{l}\text { Caregiver Survey } \\
\text { response } \\
\mathrm{N}(\%)\end{array}$ & $\begin{array}{l}\text { Young Adult Survey } \\
\text { Response } \\
\mathrm{N}(\%)\end{array}$ & $\begin{array}{l}\text { Overall } \\
\text { Response } \\
\mathrm{N}(\%) \\
\end{array}$ \\
\hline Heard of HPV & $N=41$ & $N=9$ & $N=50$ \\
\hline Yes & $13(30 \%)$ & $2(22 \%)$ & $15(28 \%)$ \\
\hline No & $28(65 \%)$ & 7 (78\%) & 35 (70\%) \\
\hline Prefer not to say & 0 & 0 & $2(4 \%)$ \\
\hline Source of information & $N=13$ & $N=2$ & $n=14$ \\
\hline Doctor & 2 & 0 & $2(14 \%)$ \\
\hline Nurse & 0 & 0 & $0(0 \%)$ \\
\hline Family member & 3 & 0 & $2(14 \%)$ \\
\hline Friend & 1 & 1 & $1(7 \%)$ \\
\hline School & 1 & & $1(7 \%)$ \\
\hline Found their own information & 6 & 1 & $6(42 \%)$ \\
\hline Other & 2 & 0 & $2(14 \%)$ \\
\hline Belief around HPV transmission & $N=15$ & $N=3$ & $N=18$ \\
\hline Kissing & $2(13 \%)$ & 1 & $3(17 \%)$ \\
\hline Sexual Contact & $11(73 \%)$ & 2 & $12(67 \%)$ \\
\hline Handshaking & 0 & 0 & 0 \\
\hline I don't know/other & $3(20 \%)$ & 0 & $3(17 \%)$ \\
\hline Heard of HPV Vaccine & $N=40$ & $N=9$ & $N=49$ \\
\hline Yes & 10 & $3(33 \%)$ & $13(26 \%)$ \\
\hline No & 30 & $6(67 \%)$ & $37(74 \%)$ \\
\hline Uncertain & 0 & 0 & 0 \\
\hline Believed the vaccine can be given to both males and females & $N=10$ & $N=3$ & $N=13$ \\
\hline Yes & $7(70 \%)$ & 1 & $8(61 \%)$ \\
\hline No & $2(20 \%)$ & 2 & $4(31 \%)$ \\
\hline Uncertain & $1(10 \%)$ & 0 & $1(8 \%)$ \\
\hline Believed the vaccine to be safe & $N=10$ & $N=3$ & $N=13$ \\
\hline Yes & $8(80 \%)$ & 2 & $10(77 \%)$ \\
\hline No & $1(10 \%)$ & & $1(8 \%)$ \\
\hline uncertain & $1(10 \%)$ & 1 & $2(15 \%)$ \\
\hline Believed the vaccine was only for those who are sexually active & $N=10$ & $N=3$ & $N=13$ \\
\hline Yes & $4(40 \%)$ & 1 & $5(38 \%)$ \\
\hline No & $6(60 \%)$ & 1 & $7(54 \%)$ \\
\hline Uncertain & & 1 & $1(8 \%)$ \\
\hline Believed the vaccine is effective in preventing certain types of cancers & $N=10$ & $N=3$ & $N=13$ \\
\hline Yes & $5(50 \%)$ & 1 & $6(46 \%)$ \\
\hline No & $3(30 \%)$ & 1 & $4(31 \%)$ \\
\hline Uncertain & $2(20 \%)$ & 1 & $3(23 \%)$ \\
\hline $\begin{array}{l}\text { Believed the vaccine is most effective if given before one become sexually } \\
\text { active }\end{array}$ & $N=10$ & $N=3$ & $N=13$ \\
\hline Yes & $8(80 \%)$ & 2 & $10(77 \%)$ \\
\hline No & 0 & & $0(0 \%)$ \\
\hline Uncertain & $2(20 \%)$ & 1 & $3(23 \%)$ \\
\hline Believed the vaccine can cure the disease & $N=10$ & $N=3$ & $N=13$ \\
\hline
\end{tabular}


Table 3 Knowledge and Beliefs around HPV and HPV vaccine (Continued)

\begin{tabular}{|c|c|c|c|}
\hline & $\begin{array}{l}\text { Caregiver Survey } \\
\text { response } \\
\mathrm{N}(\%)\end{array}$ & $\begin{array}{l}\text { Young Adult Survey } \\
\text { Response } \\
\mathrm{N}(\%)\end{array}$ & $\begin{array}{l}\text { Overall } \\
\text { Response } \\
\text { N (\%) }\end{array}$ \\
\hline Yes & $4(40 \%)$ & 1 & $5(38 \%)$ \\
\hline No & $4(40 \%)$ & 2 & $6(46 \%)$ \\
\hline Uncertain & $2(20 \%)$ & 0 & $2(15 \%)$ \\
\hline Believed the vaccine protects against all sexually transmitted infections & $N=10$ & $N=3$ & $N=13$ \\
\hline Yes & $3(30 \%)$ & & $4(31 \%)$ \\
\hline No & $6(50 \%)$ & 3 & $8(61 \%)$ \\
\hline Uncertain & $1(10 \%)$ & & $1(8 \%)$ \\
\hline Worried that the vaccine can cause bad side effects & $N=10$ & $N=3$ & $N=13$ \\
\hline Yes & $3(30 \%)$ & 1 & $4(31 \%)$ \\
\hline No & $6(60 \%)$ & 2 & $8(61 \%)$ \\
\hline uncertain & $1(10 \%)$ & & $1(8 \%)$ \\
\hline Believed that giving a child the vaccine will encourage them to have sex & $N=10$ & & $N=10$ \\
\hline Yes & $1(10 \%)$ & & $1(10 \%)$ \\
\hline No & $8(80 \%)$ & & $8(80 \%)$ \\
\hline uncertain & $1(10 \%)$ & & $1(10 \%)$ \\
\hline Will you have your child vaccinated? & $N=41$ & & \\
\hline Will be vaccinated & $15(36 \%)$ & & \\
\hline No, will not receive the vaccine & $7(17 \%)$ & & \\
\hline Undecided & $13(32 \%)$ & & \\
\hline Prefer not to say & $6(15 \%)$ & & \\
\hline Will you or have you been vaccinated & & $N=6$ & \\
\hline vaccinated & & $1(17 \%)$ & \\
\hline not vaccinated & & $3(50 \%)$ & \\
\hline Undecided & & $2(33 \%)$ & \\
\hline Vaccinate child even if had to pay & $N=36$ & & \\
\hline Yes & $12(33 \%)$ & & \\
\hline No & $7(19 \%)$ & & \\
\hline Uncertain & $17(47 \%)$ & & \\
\hline Will you vaccinate your child if it was free/publicly funded? & $N=36$ & & \\
\hline Yes & $11(31 \%)$ & & \\
\hline No & $13(36 \%)$ & & \\
\hline Uncertain & $12(33 \%)$ & & \\
\hline Opinions of friends and family influence my decision & $N=37$ & $N=2$ & $N=39$ \\
\hline Yes & $10(27 \%)$ & & $10(26 \%)$ \\
\hline No & $19(51 \%)$ & 2 & $21(54 \%)$ \\
\hline Uncertain & $8(22 \%)$ & & $8(20 \%)$ \\
\hline Willing to get the vaccine if recommended by the doctor & $N=41$ & & \\
\hline Yes & $19(46 \%)$ & & \\
\hline No & $0(0 \%)$ & & \\
\hline Uncertain & 8 (19\%) & & \\
\hline No response & $14(34 \%)$ & & \\
\hline
\end{tabular}

Participants were able to choose one or more response in questions about HPV knowledge source and how HPV transmitted 
Participants who answered yes to the question about whether they had heard of HPV were asked additional questions pertaining to their level of knowledge of HPV and the HPV vaccine. Fifteen out of 50 respondents had heard of HPV (28\%) and 2 preferred not to say (4\%). Of these, only 2 respondents' source of knowledge was from either a Doctor or Nurse (14\%). Other sources of information included family members $(n=2,14 \%)$, friends $(n=1,7 \%)$, school $(n=1,7 \%)$, finding their own information $(4,43 \%)$ and 'other' $(n=2,14 \%)$.

We asked the 15 participants who had heard of HPV questions about their HPV knowledge and 18 responses were provided. Twelve respondents ( $80 \%$ of respondents) knew that HPV is sexually transmitted. Of the 13 participants who had heard of the HPV vaccine, 5 (36\%) believed that the HPV vaccine was only for those who are sexually active and only 8 (61\%) believed that the vaccine was available for both men and women. Of the participants who had heard of the HPV vaccine, 6 participants $(46 \%)$ knew that it is effective in preventing certain types of cancer. Nearly $40 \%(n=5)$ incorrectly believed that the vaccine can cure HPV. Only 1 respondent answered all 6 questions correctly.

\section{HPV vaccine beliefs}

Ten of the 13 participants (77\%) who had heard of the HPV vaccine believed that the vaccine is safe, and 8 (61\%) stated that they were not worried about its sideeffects; however, when these individuals who had heard of the vaccine were asked about intent to vaccinate, less than two-thirds of these respondents said they would accept (or have already accepted) the HPV vaccine $(n=$ $8,62 \%)$.

Thirty-six out of the forty-one caregivers who completed the survey answered the question about discussing sexual health with their children. Only 16 of the 36 respondents (44\%) reported feeling comfortable having these discussions. Among the caregiver population, 10 participants had heard of HPV $(28 \%) .80 \%(n=8)$ of caregivers who had heard of the vaccine believed that having their child vaccinated against HPV would not encourage promiscuity. Furthermore, all 8 of these participants who did not believe the vaccine promoted sexual behaviour also felt comfortable talking to their children about sexual health. However, during the qualitative interviews some parents reported feeling uncomfortable discussing sexual health with their children, especially with their daughters (Table 2). One participant was quoted as saying: "I believe this is a bit difficult to speak about .... Africans don't talk a lot about sex with their children. If it's with girls, no it is difficult, with boys I can see us talking a little bit, but not in depth. With girls it is very difficult."
Young adults were asked whether they were comfortable talking about health-related issues including sexual health with their parents. Only 4 provided an answer to this question, of which 1 answered yes. All participants who chose not to answer this question were 21 years of age or older.

\section{Access and acceptance of vaccination}

Willingness to vaccinate was not associated with region of origin, language, sex, level of education or newcomer status (e.g., immigrant, refugee). In terms of cost, onethird of respondents $(n=12)$ indicated that they would accept the vaccine even if they had to pay for it. The remaining two-thirds $(n=24)$ were either unsure whether they would accept the vaccine or stated that they would only accept the vaccine if it was free. One interviewee stated "if it's affordable, I really don't mind because we are talking about life here".

Despite not previously hearing of HPV or the vaccine, many newcomers expressed willingness to have their children vaccinated or to be vaccinated themselves. Of the 41 participants who completed the caregiver survey, $15(36 \%)$ indicated that they would have their children vaccinated against HPV, 19 (46\%) preferred not to say or were undecided. There was an association between willingness to have their child vaccinated and level of education, although this did not reach significance $\left(X^{2}(4, N=\right.$ $41)=8.9419, p=0.063$ ). Willingness of caregivers to have children vaccinated was not associated with caregiver age $\left(X^{2}(4, N=41)=1.4418, p=0.837\right)$ or gender $\left(X^{2}(2\right.$, $N=41)=1.566,0.457)$.

Of the 26 individuals who decided not to vaccinate their child against HPV or had not yet decided, 18 (69\%) said that they would accept the vaccine if it was recommended by a clinician. No participants indicated that they would definitely refuse the vaccine if a doctor recommended it.

\section{Interviewer: "If your doctor was to say, "I think that your child should be vaccinated." Would that influ- ence your decision"? \\ "It's okay. I am sure the doctor will never mislead".}

Only 3 survey respondents provided a response when asked why they would not have their child vaccinated. The following responses were provided: 'I would want to discuss it with her father'; 'they will be educated about sexual health'; 'my decision would depend on my doctor's opinion. If he said to give it to my child, I would do it.'

Of the 9 participants who completed the young adult survey, 6 answered the question about receiving the vaccine. Of these, 1 participant (17\%) had already received the vaccine, $2(33 \%)$ had not been vaccinated and 3 
(50\%) had not yet decided whether they would receive the vaccine.

Participants who completed the interviews were asked to give suggestions on how to inform newcomers to Canada about the HPV vaccine. Two participants suggested culturally- and language-appropriate materials should be made available in doctors' offices or in the community and one participant suggested that newcomers should be educated during the immigration process.

\section{Discussion}

This study sought to understand barriers to newcomers' uptake of the HPV vaccine by surveying 50 individuals who self-identified as newcomers to Canada about their knowledge, attitudes, and beliefs regarding HPV and the HPV vaccine. The survey highlighted considerable gaps in newcomers' awareness of both HPV and the vaccine, with most participants reporting never having heard of either. Among those who had heard of HPV and/or the vaccine, misconceptions were common.

The lack of knowledge about HPV demonstrated by the participants in our study is not unique, and has been documented among newcomers in a variety of contexts due to a combination of systemic and cultural factors [10, 19-21]. These issues of low HPV-knowledge also appeared in our work exploring healthcare providers' perceptions about newcomer uptake of the HPV vaccine
[22] and a systematic review of studies exploring barriers to vaccination faced by newcomers generally [14]. Newcomers often report a complete lack of awareness of the HPV vaccine [23, 24], as was the case for nearly threequarters $(74 \%)$ of participants in our current study.

Cultural factors can also play a substantial role in newcomers' HPV vaccine decision-making. Specifically, cultural taboos around discussing sexuality and concerns that the vaccine will promote promiscuity have been documented as important barriers for many newcomers [10]. For participants in our study who were already familiar with the HPV vaccine, this did not appear to be an issue, as those who felt comfortable discussing sexuality with their children did not believe the vaccine contributed to sexual activity. However, in the qualitative interviews, participants did report experiencing difficulty discussing sexuality with their children, particularly their daughters. See Fig. 1 for a full comparison and consolidation of the findings from our previous studies.

Vaccine hesitancy that is associated with deeply-held beliefs such as religion or culture can be very resistant to change. However, it is important to note that newcomers may be more receptive to vaccination overall than members of the general population [19] and that many participants in this study reported being undecided with respect to accepting the HPV vaccine for themselves or their children rather than opposed to it.

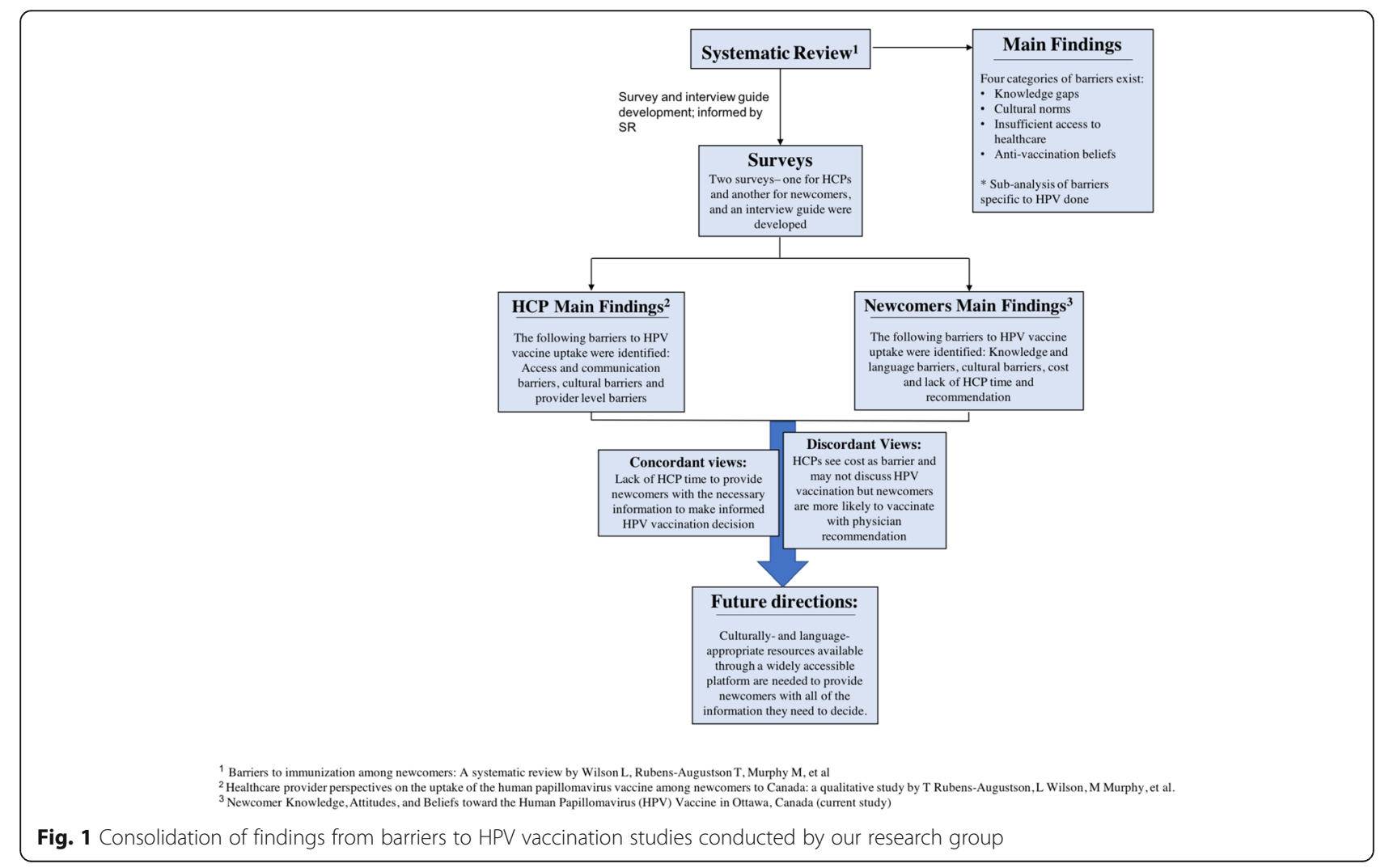


Table 4 Summary of barriers to HPV vaccination in newcomers

\begin{tabular}{|c|c|c|c|c|c|c|c|}
\hline Reference & $\begin{array}{l}\text { Study } \\
\text { setting }\end{array}$ & Sample Size & $\begin{array}{l}\text { Country } \\
\text { of } \\
\text { Origin/ } \\
\text { Ethnicity }\end{array}$ & Objectives & Methods & Results & Conclusion \\
\hline
\end{tabular}

\begin{tabular}{llll}
\hline $\begin{array}{l}\text { Grandahl } \\
\text { et al., }\end{array}$ & Sweden $n=50$, women & Middle & To explore immigrant \\
2015 [29] & aged 18-54 & East, & women's experiences \\
& & Africa, & and views on the \\
& & Asia, East & prevention of cervical \\
& & Europe & cancer, screening, HPV \\
& & vaccination and \\
& & condom use.
\end{tabular}

Aragones

et al.,

2017 [19]

\section{USA}

\author{
$n=36$, parents of Latin \\ minors (i.e., 9-17 America \\ year old) who \\ had not initiated \\ the HPV vaccine \\ series for their \\ child
}

Stephens

\& Thomas,

2014 [30]
USA

$n=31$, women, with a daughter between 11 and 18 years old

\begin{tabular}{|c|c|c|c|c|}
\hline $\begin{array}{l}\text { Kobetz } \\
\text { et al., } \\
2011 \text { [21] }\end{array}$ & USA & $\begin{array}{l}n=41 \text { women } \\
\text { aged } 21-75\end{array}$ & Haiti & $\begin{array}{l}\text { To examine Haitian } \\
\text { women's perceptions } \\
\text { of, and barriers to, HPV } \\
\text { vaccination }\end{array}$ \\
\hline
\end{tabular}

McComb

et al.,

2018 [10]
Haiti

To identify cultural beliefs influencing immigrant Haitian mothers' willingness to vaccinate their daughters against HPV
To elucidate Latino immigrant parents barriers to obtaining the HPV vaccine for their children

\section{8 focus group Emergent themes: \\ $\begin{array}{ll}8 \text { focus group } & \text { Emergent themes: } \\ \text { interviews, 5-8 } & \text { 1) deprioritization of }\end{array}$ /group

(1) women's health in home countries \\ 2) positive attitudes of availability of women's health in Sweden 3) positive and negative attitudes towards HPV vaccination \\ 4) communication barriers limit health care access.}

5 focus groups, Three major findings 5-10/group were: (1) low levels of awareness and knowledge of HPV and the HPV vaccine, (2) increased confidence that parent can access the vaccine for their eligible child and (3) lack of provider recommendation as the main barrier to vaccination.

Survey assessing HPV and HPV vaccine knowledge, followed by a semistructured interview.

Mothers had low levels of HPV and HPV vaccine knowledge, and asked for more information. Concerns centered on cultural values regarding adolescent sexuality and HIV/AIDS stigmas specific to Haitian communities.

5 focus groups, Amongst those 8/group participants who had heard of HPV, many held misconceptions about virus transmission and did not understand the role of HPV in the development of cervical cancer. All participants showed support for vaccines as beneficial for health.

Exploring underlying Semi- Participants had limited Most women perceived reasons for lower structured uptake of (HPV) vaccine interviews among new immigrants and refugees

knowledge about HPV and the HPV vaccine. that their risk of HPV was low, however showed willingness to receive the vaccine if it were recommended by their physician.

Yi et al., 2013 [28]
USA $\quad n=113$, women Vietnam aged 18 or older
To determine receipt of semi structured Women who were less HPV vaccine and assess interviews proficient in English if limited English proficiency and
Women wanted to participate in cervical cancer prevention and would accept HPV vaccination for their daughters but faced barriers to information from HCP (language, cultural norms)

ncreased provider recommendation for the HPV vaccine while providing tailored HPV information to parents.

Vaccination uptake could increase if recommended by a physician. Uptake efforts should emphasize physician involvement and incorporate culturally relevant health concerns.

Addressing gaps such as lack of educational information available in Haiti language about HPV and cervical cancer.

Efforts are required to increase knowledge about HPV among immigrant and refugee women and support for physicians to discuss and offer vaccination to this population.

There is a need for public health evaluation and education programs on HPV and cervical 
Table 4 Summary of barriers to HPV vaccination in newcomers (Continued)

\begin{tabular}{|c|c|c|c|c|c|c|c|}
\hline Reference & $\begin{array}{l}\text { Study } \\
\text { setting }\end{array}$ & Sample Size & $\begin{array}{l}\text { Country } \\
\text { of } \\
\text { Origin/ } \\
\text { Ethnicity }\end{array}$ & Objectives & Methods & Results & Conclusion \\
\hline & & & & $\begin{array}{l}\text { knowledge related to } \\
\text { HPV vaccine were } \\
\text { associated with HPV } \\
\text { vaccine uptake }\end{array}$ & & $\begin{array}{l}\text { vaccination. Participants } \\
\text { lacked knowledge of } \\
\text { HPV. }\end{array}$ & $\begin{array}{l}\text { cancer designed for } \\
\text { Vietnamese-American } \\
\text { women }\end{array}$ \\
\hline $\begin{array}{l}\text { Lee \& Lee, } \\
2017 \text { [24] }\end{array}$ & USA & $\begin{array}{l}n=16, \text { women, } \\
\text { aged } 21 \text { and } \\
\text { older }\end{array}$ & Korea & $\begin{array}{l}\text { This study aimed to } \\
\text { identify major barriers } \\
\text { to Papanicolaou (Pap) } \\
\text { test uptake and HPV } \\
\text { vaccine acceptability. }\end{array}$ & $\begin{array}{l}3 \text { focus groups } \\
\text { with } 16 \\
\text { women }\end{array}$ & $\begin{array}{l}\text { Three major themes } \\
\text { emerged as barriers: 1) } \\
\text { limited knowledge } \\
\text { about cervical cancer } \\
\text { and preventive } \\
\text { behaviors, 2) culture- } \\
\text { specific barriers, and 3) } \\
\text { low accessibility to } \\
\text { health care services. }\end{array}$ & $\begin{array}{l}\text { Culturally tailored } \\
\text { cervical cancer } \\
\text { education is needed to } \\
\text { promote Pap test uptake } \\
\text { and HPV vaccination in } \\
\text { this population. }\end{array}$ \\
\hline $\begin{array}{l}\text { Luque } \\
\text { et al., } \\
2010 \text { [23] }\end{array}$ & USA & $\begin{array}{l}n=80, \text { women, } \\
\text { aged } 18 \text { to } 55 \\
n=17, \text { HCW's, }^{\prime} \\
\text { average age } 42 .\end{array}$ & $\begin{array}{l}\text { Mexico, } \\
\text { Hondurus, } \\
\text { Peurto } \\
\text { Rico, USA }\end{array}$ & $\begin{array}{l}\text { To explore knowledge, } \\
\text { attitudes, and beliefs } \\
\text { regarding HPV, the HPV } \\
\text { vaccine, and cervical } \\
\text { cancerscreening }\end{array}$ & Surveys & $\begin{array}{l}\text { Mexicans and } \\
\text { Hondurans had different } \\
\text { perceptions of risk } \\
\text { factors and lower levels } \\
\text { of HPV knowledge than } \\
\text { Puerto Ricans or Anglo- } \\
\text { Americans. }\end{array}$ & $\begin{array}{l}\text { Target areas for health } \\
\text { education based on } \\
\text { resulting cultural models } \\
\text { of illness need to be } \\
\text { identified }\end{array}$ \\
\hline $\begin{array}{l}\text { Scarinci } \\
\text { et al., } \\
2007 \text { [20] }\end{array}$ & USA & $\begin{array}{l}n=55, \text { women, } \\
\text { aged } 17 \text { and } 39 \\
\text { years old }\end{array}$ & $\begin{array}{l}\text { Latinas } \\
\text { and } \\
\text { African } \\
\text { Americans }\end{array}$ & $\begin{array}{l}\text { To examine the } \\
\text { acceptability of } \\
\text { preventive HPV } \\
\text { vaccination among } \\
\text { Latina immigrants and } \\
\text { African American } \\
\text { women }\end{array}$ & $\begin{array}{l}8 \text { focus groups } \\
\text { were } \\
\text { conducted }\end{array}$ & $\begin{array}{l}\text { The motivating factors } \\
\text { for vaccine use included } \\
\text { (1) receiving education/ } \\
\text { information about the } \\
\text { vaccine through } \\
\text { healthcare providers, (2) } \\
\text { affordable prices, (3) } \\
\text { good results in trials, and } \\
\text { (4) knowing others who } \\
\text { had already gotten } \\
\text { vaccinated. }\end{array}$ & $\begin{array}{l}\text { These findings suggest } \\
\text { that unique educational } \\
\text { strategies need to be } \\
\text { developed, based on the } \\
\text { needs and perceptions } \\
\text { of the targeted } \\
\text { audience, in order to } \\
\text { achieve wide-spread ac- } \\
\text { ceptability of this } \\
\text { vaccine. }\end{array}$ \\
\hline
\end{tabular}

Previous research has shown that a healthcare provider's recommendation is a strong predictor of HPV vaccination and is crucial to increasing vaccine uptake [24, 25]. This finding is corroborated by the participants in our study, nearly half of whom indicated that their indecision could be overcome by a healthcare provider's recommendation. Time spent by healthcare providers to fully engage with newcomers about HPV vaccination to provide information and/or clarify common misunderstandings or misconceptions about the vaccine is needed $[21,26]$ but not always feasible [22]. Here we also reported that only 2 participants had heard about HPV from a doctor or nurse. There is a need for culturallyand language-appropriate solutions that allow healthcare provider engagement and promote health literacy for newcomers without further taxing providers [27].

We reviewed the existing literature on barriers to HPV vaccine among newcomers and have summarized this in Table 4. These 9 studies identified a number of barriers contributing to low HPV vaccine uptake in immigrant populations that align with the findings of our study. Specifically, Yi et al. found that women who were less proficient in English were less likely to receive the HPV vaccine due to difficulty in understanding the educational material [28]. Participants whose cultural norms were taken into consideration were more likely to receive a vaccine $[24,29,30]$. Consistent with our current study, four studies identified a gap in healthcare provider recommendation and participants indicated that if their healthcare provider recommended it, they would consider getting the vaccine $[20,23,30]$.

We identified 3 main strengths of this study. First, this study examined an issue of high public health importance and highlighted a need for health care engagement to promote HPV vaccine uptake in newcomer populations, which is supported by the literature. Second this study was conducted in a city with a high newcomer population, thus the outcomes we have identified are more likely to reflect the experiences of the broader newcomer population in Canada. Finally, the use of both quantitative and qualitative approaches allowed us to build upon survey findings.

A primary limitation of this study is its small sample size. Given the exploratory nature of this study, we relied 
on a convenience sampling approach, limiting generalizability. As our participants were recruited from $\mathrm{CHCs}$ in Ottawa, it is possible that our findings may not be applicable to other centers or other newcomer populations we did not reach. Additionally, because our participants already use the healthcare services offered by CHCs, it is plausible that these newcomers were more engaged in the Canadian healthcare system and may thus face different barriers than people who are less familiar with the health services offered for newcomers. Finally, because the study design was reliant on self-reported behaviours or intended behaviours, this study may suffer from issues of social desirability bias. As the study was conducted in $\mathrm{CHCs}$ that offer vaccination and given that participants knew that the nature of the study was to explore barriers to vaccination, they may have felt compelled to report higher levels of vaccine acceptance than they would have in other circumstances.

\section{Conclusions}

Our study indicates that there are considerable gaps in newcomers' awareness and understanding of HPV and HPV vaccination. Healthcare providers should seek to find ways to equip newcomers with culturally and language-appropriate resources to make informed vaccine decisions. A standardized approach could overcome language and communication issues and would allow for common information to be conveyed to patients. Future research should seek to engage a wider variety of newcomers in order to determine which barriers occur across newcomer populations and context.

\section{Supplementary Information}

The online version contains supplementary material available at https://doi. org/10.1186/s12875-020-01360-1.

Additional file 1: Table S1. Qualitative Interview Guide.

\section{Abbreviations}

HPV: Human papillomavirus; KAB: Knowledge, attitudes and beliefs; CHCs: Community health centres

\section{Acknowledgements}

We would like to thank the staff at the community health centres who facilitated recruitment and organized events on our behalf as well as our study participants, without whom this work would not have been possible.

\section{Authors' contributions}

$L A W, A Q, K W, C J, K P, N C, C H$ conceptualized, designed and oversaw the research; LAW and MP conducted interviews and performed study related activities, $A Q, A B B$, LAW analyzed the data; $L A W, A Q$ conducted the qualitative analysis; $L A W, A Q, A B B, S S M$ wrote and revised the manuscript; all authors reviewed and approved the final manuscript.

\section{Funding}

This research was supported by the Canadian Institute of Health Research (HPV-155394). The funder had no role in study design and collection, analysis, interpretation or manuscript writing.
Availability of data and materials

The datasets used and/or analyzed during the current study are available from the corresponding author on reasonable request.

\section{Ethics approval and consent to participate}

The study and all study materials were approved by the Ottawa Health Science Network Research Ethics Board (OHSN-REB \#20170913-01H). All participants provided informed written consent prior to participating in any study-related activities.

\section{Consent for publication}

Not applicable.

\section{Competing interests}

The authors declare that they have no competing interests.

\section{Author details}

${ }^{1}$ Clinical Epidemiology Program, Ottawa Hospital Research Institute, Administrative Services Building, Box 684, 1053 Carling Avenue, Ottawa, ON K1Y 4E9, Canada. ${ }^{2}$ Faculty of Health Sciences, University of the Fraser Valley, 45190 Caen Ave., Chilliwack, BC V2R0N3, Canada. ${ }^{3}$ Faculty of Medicine, University of Ottawa, 451 Smyth Rd, Ottawa, ON K1H 8M5, Canada. ${ }^{4}$ Bruyère Research Institute, 85 Primrose Ave, Ottawa, ON K1R 6M1, Canada. ${ }^{5}$ Public Health Ontario, 480 University Avenue, Suite 300, Toronto, Ontario M5G, Canada. ${ }^{6}$ Department of Medicine, University of Ottawa, 451 Smyth Rd, Ottawa, ON K1H 8M5, Canada.

Received: 15 July 2020 Accepted: 20 December 2020

Published online: 09 January 2021

\section{References}

1. World Health Organization. Human papillomavirus (HPV) and cervical cancer. Fact Sheets. 2018.

2. Steben M, Durand N, Guichon JR, Greenwald ZR, McFaul S, Blake J. A National Survey of Canadian physicians on HPV: knowledge, barriers, and preventive practices. J Obstet Gynaecol Canada. 2019;41(5):599-607.

3. Canadian Cancer Society's Advisory Committee on Cancer Statistics. Canadian Cancer Statistics Special topic: HPV-associated cancers. Canadian Cancer Statistics 2016. Toronto, Canada; 2016.

4. Hariri S, Johnson ML, Bennett NM, Bauer HM, Park IU, Schafer S, et al. Population-based trends in high-grade cervical lesions in the early human papillomavirus vaccine era in the United States. Cancer. 2015;121(16):2775-81.

5. Crowe E, Pandeya N, Brotherton JML, Dobson AJ, Kisely S, Lambert SB, et al. Effectiveness of quadrivalent human papillomavirus vaccine for the prevention of cervical abnormalities: case-control study nested within a population based screening programme in Australia. BMJ. 2014;348:g1458.

6. Drolet M, Bénard É, Pérez N, Brisson M, Ali H, Boily MC, et al. Populationlevel impact and herd effects following the introduction of human papillomavirus vaccination programmes: updated systematic review and meta-analysis. Lancet. 2019;394(10197):497-509.

7. Salvadori MI. Human papillomavirus vaccine for children and adolescents. Paediatr Child Health. 2018;23(4):262-5.

8. Bird Y, Obidiya O, Mahmood R, Nwankwo C, Moraros J. Human papillomavirus vaccination uptake in canada: A systematic review and metaanalysis. Int J Prev Med. 2017:8:71.

9. Newman PA, Logie CH, Lacombe-Duncan A, Baiden P, Tepjan S, Rubincam C, et al. Parents' uptake of human papillomavirus vaccines for their children: A systematic review and meta-analysis of observational studies. BMJ Open. BMJ Publishing Group. 2018:8:e019206.

10. McComb E, Ramsden V, Olatunbosun O, Williams-Roberts H. Knowledge, Attitudes and Barriers to Human Papillomavirus (HPV) Vaccine Uptake Among an Immigrant and Refugee Catch-Up Group in a Western Canadian Province. J Immigr Minor Heal. 2018;20:6(1424-1428).

11. Immunize BC. HPV (Human Papillomavirus); 2020. www.immunizebc.ca.

12. Statistics Canada. Immigration and ethnocultural diversity: key results from the 2016 census. Dly; 2017. p. 1-8.

13. Statistics Canada. Immigration and Ethnocultural Diveresity - Ottawa Gatineau. Focus on Geography Series, 2016 Census. 2017.

14. Wilson L, Rubens-Augustson T, Murphy M, Jardine C, Crowcroft N, Hui C, et al. Barriers to immunization among newcomers: a systematic review. Vaccine. 2018;36(8):1055-62. 
15. Pottie K, Greenaway C, Feightner J, Welch V, Swinkels H, Rashid M, et al. Evidence-based clinical guidelines for immigrants and refugees. CMAJ. Canadian Medical Association. 2011;183:E824-925.

16. Pottie K, Nolen A, Topp P, Torres S, Welch V, Durand N. Appendix 19: Cervical cancer: evidence review for newly arriving immigrants and refugees Canadian Collaboration for Immigrant and Refugee Health (CCIRH) The case. 2011 [cited 2020 Jun 4]; Available from: www.phac-aspc.gc.ca/naci-ccni.

17. Crawford J, Ahmad F, Beaton D, Bierman AS. Cancer screening behaviours among South Asian immigrants in the UK, US and Canada: a scoping study. Health Soc Care Community. 2016;24(2):123-53. [cited 2020 Jun 3] Available from. https://doi.org/10.1111/hsc.12208.

18. Corbin, J, Strauss A. Basics of Qualitative Research. 4rth Ed. Sage Publications Inc; 1992.

19. Aragones A, Genoff M, Gonzalez C, Shuk E, Gany F. HPV vaccine and Latino immigrant parents: if they offer it, we will get it. J Immigr Minor Health. 2016;18(5):1060-5.

20. Scarinci IC, Garces-Palacio IC, Partridge EE. An examination of acceptability of HPV vaccination among African American women and Latina immigrants. J Women's Heal. 2007;16(8):1224-33.

21. Kobetz E, Menard J, Hazan G, Koru-Sengul T, Joseph T, Nissan J, et al. Perceptions of HPV and cervical cancer among Haitian immigrant women: implications for vaccine acceptability. Educ Health (Abingdon). 2011;24(3):479.

22. Rubens-Augustson T, Wilson LA, Murphy MS, Jardine C, Pottie K, Hui C, et al. Healthcare provider perspectives on the uptake of the human papillomavirus vaccine among newcomers to Canada: a qualitative study. Hum Vaccin Immunother. 2019:15((7-8):1697-707.

23. Luque JS, Castaneda H, Tyson DM, Vargas N, Proctor S, Meade CD. HPV awareness among Latina immigrants and Anglo American women in the Southern u.s.: cultural models of cervical cancer risk factors and beliefs. NAPA Bull. 2010;34(1):84-104.

24. Lee H, Lee M. Barriers to cervical Cancer screening and prevention in young Korean immigrant women: implications for intervention development. J Transcult Nurs. 2017;28(4):353-62.

25. Dailey PM, Krieger JL. Communication and US-Somali immigrant human papillomavirus (HPV) vaccine decision-making. J Cancer Educ. 2015;32(3): 516-21.

26. Quach S, Hamid JS, Pereira JA, Heidebrecht CL, Deeks SL, Crowcroft NS, et al. Influenza vaccination coverage across ethnic groups in Canada. Can Med Assoc J. 2012;184(15):1673-81.

27. Hui C, Dunn J, Morton R, Staub L, Tran A, Hargreaves S, et al. Interventions to improve vaccination uptake and cost effectiveness of vaccination strategies in newly arrived migrants in the EU/EEA: a systematic review. Int J Environ Res Public Health. 2018;15(10):2065.

28. Yi JK, Anderson KO, Le YC, Escobar-Chaves SL, Reyes-Gibby CC. English proficiency, knowledge, and receipt of HPV vaccine in Vietnamese-American women. J Community Health. 2013;38(5):805-11.

29. Grandahl M, Tydén T, Gottvall M, Westerling R, Oscarsson M. Immigrant women's experiences and views on the prevention of cervical cancer: a qualitative study. Health Expect. 2015;18(3):344-54.

30. Stephens DP, Thomas TL. Cultural values influencing immigrant Haitian mothers' attitudes toward human papillomavirus vaccination for daughters. J Black Psychol. 2013;39(2):156-68.

\section{Publisher's Note}

Springer Nature remains neutral with regard to jurisdictional claims in published maps and institutional affiliations.

Ready to submit your research? Choose BMC and benefit from:

- fast, convenient online submission

- thorough peer review by experienced researchers in your field

- rapid publication on acceptance

- support for research data, including large and complex data types

- gold Open Access which fosters wider collaboration and increased citations

- maximum visibility for your research: over $100 \mathrm{M}$ website views per year

At BMC, research is always in progress.

Learn more biomedcentral.com/submissions 